DOI: 10.46340/eppd.2021.8.2.5

\author{
Yulia Okunovska, PhD in Political Science \\ ORCID ID: https://orcid.org/0000-0002-1637-175X \\ Vasyl' Stus Donetsk National University, Vinnytsia, Ukraine
}

\title{
ACTIVITY OF NON-GOVERNMENTAL ORGANIZATIONS OF UKRAINE AND POLAND IN THE CONTEXT OF CROSS-BORDER COOPERATION
}

\author{
Юля Окуньовська, к .політ. н. \\ Донецький національний університет імені Василя Стуса, Вінниця, Україна

\section{ДІЯЛЬНІСТЬ ГРОМАДСЬКИХ ОРГАНІЗАЦІЙ УКРАЇНИ ТА ПОЛЬЩІ У КОНТЕКСТІ ТРАНСКОРДОННОГО СПІВРОБІТНИЦТВА}

Polish NGOs play an active role in the transformation processes of the Ukrainian society, playing a role of a certain catalyst of the Ukrainian-Polish cross-border cooperation. The issues of public involvement and state support in the context of cross-border cooperation are still relevant to the Ukrainian public sector.

Polish NGOs help Ukraine gain the European experience of shaping the civil society, thus integrating further and further into the Ukrainian society.

The article defines the peculiarities of cross-border cooperation of Ukraine and Poland through the prism of NGOs' activity.

Poland, as well as Ukraine, has a relatively short experience of NGO functioning, however, the democratic and institutional changes that have already taken place in the Polish society are relevant for the study of the given topic.

It has been determined that in the context of NGOs' activity cross-border cooperation is an important element of the integration process that is carried out by optimal combination of the possibilities and resources of the border regions.

The article studies the particular importance of studying the Ukrainian-Polish cross-border region and determines the perspectives for further research. It discloses the essence of the activity of Poland-oriented NGOs in Ukraine taking into consideration the territorial peculiarities.

It has been determined that ethnic Poles in Ukraine participate in the public and political life of the country, are active and efficient participants of the Ukrainian-Polish partnership, which in conditions of globalization processes goes beyond the scope of mere bilateral cooperation.

The article defines cooperation of the regions of Ukraine and Poland in the context of interaction with international organizations and institutions as relevant vectors of further studies.

Keywords: cross-border cooperation, NGOs, interregional cooperation, civil society, euroregions.

\section{Постановка проблеми.}

На даний час актуальним є вивчення транскордонного співробітництва між Україною та країнами $€ C$, що здійснюється в межах правових норм європейського та національного законодавства, Державної програми розвитку транскордонного співробітництва на 20162020 роки, Угоди про асоціацію між Україною та ЄС, Європейської політики сусідства та чотирьох програм Європейського інструменту політики сусідства на 2016-2020 рр. («УкраїнаПольща-Білорусь», «Україна-Словаччина-Угорщина-Румунія», «Україна-Румунія», «Басейн Чорного моря»), Стратегії Європейського Союзу для Дунайського регіону, міждержавних угод з Польщею, Румунією, Словаччиною, Угорщиною. Подальший розвиток транскордонного співробітництва в умовах євроінтеграційних змін, імплементації Угоди про асоціацію, 
трансформації соціально-економічного розвитку України потребує удосконалення вивчення участі у цих процесах організацій «третього сектору».

Термін «транскордонне співробітництво» був уведений Мадридською Конвенцією загальних принципів транскордонного співробітництва. Основні положення щодо транскордонного співробітництва закріплені у європейському законодавстві, а саме у «Європейській рамковій конвенції про транскордонне співробітництво між територіальними общинами» ${ }^{1}$.

Основна суть даного терміну полягає у спільних діях, які спрямовані на встановлення i поглиблення економічних, громадянських, соціальних, екологічних, культурних та інших відносин. У першу чергу встановлення співробітництва відбувається через співпрацю громад, представницьких органів, місцеві органи виконавчої влади.

Важливим аспектом дослідження є той факт, що транскордонне співробітництво в умовах розвитку інтеграційних процесів має властивість прискорювати процеси вирівнювання якості життя населення прикордонних територій та сприяти створенню умов для вільного переміщення людей, товарів, капіталів та послуг через кордон у тому чисті і в контексті розвитку громадянського суспільства. Транскордонне співробітництво відіграє також важливу роль в якості специфічного «полігону» для адаптації європейського законодавства та механізмів фінансової підтримки.

Метою статті $\epsilon$ вивчення особливості транскордонного співробітництва України та Польщі через призму діяльності громадських організацій.

Виклад основного матеріалу. Українсько-польське транскордонне співробітництво охоплює територію трьох прикордонних областей України (Волинська, Львівська та Закарпатська) та двох воєводств Республіки Польща (Люблінське та Підкарпатське).

Як в українській, так і в польській частині спостерігається тенденція до зростання кількості громадських організацій. Відхилення у кількості громадських організацій української частини до польської становить близько 50\%.

Громадський сектор України порівняно з польським перебуває у періоді становлення. Лише на початку 1990-х років в Україні зростала кількість громадських організацій, але діяльність переважної більшості з них тяжіла до формалізму. Заважала доволі слабка фінансова та інституційна спроможність неурядових громадських організацій. У нашій державі не було створено належного законодавства, зокрема стосовно джерел фінансування інституцій громадянського суспільства.

Від проголошення незалежності в Україні почався процес інституалізації різноманітних форм громадянського суспільства. Було зроблено спроби «інвентаризації» та класифікації тих організацій, що входять до «третього сектора»: неприбуткових недержавних організацій²

Результатом стало видання Довідника, що охоплює НУО або НДО (неурядові чи недержавні організації, що одне й те ж) усіх областей України, вийшов у 1997 р. (видання Творчого Центру КАУНТЕРПАРТ та Фондів «Counterpart», «Свразія» та Міжнародного Фонду «Відродження»).Даний довідник налічує 1631 організацію, подає їхні адреси, а також вказує на напрям та вид діяльності кожної організації. Львівське обласне управління статистики та Фонд розвитку громадських організацій «Західноукраїнський ресурсний центр» у 1998 р. опублікували подібний довідник, що стосується Львівської області. Він містить 1830 назв легалізованих об’єднань Львівщини (з них 990 діють в обласному центрі), а також деякі узагальнені рисунки і таблиці. ЗУРЦ видає журнал «Громадські ініціативи», в якому систематично публікується як інформація про окремі громадські НДО, так і огляди розвитку громадянського суспільства в Україні загалом та іiі західному регіоні, зокрема. Те ж саме можна сказати й про журнали інших фондів розвитку НДО - «Інтеграл» (Одеса), Бюлетень СУРЦ, а також загальноукраїнські видання «Голос громадянина», «Перехрестя», «Громада» ${ }^{3}$.

Становлення громадянського суспільства як гарантії демократичного розвитку України визначено одним із напрямів іiї внутрішньої політики. Відповідно до Закону України «Про засади внутрішньої і зовнішньої політики» від 1 липня 2010 року, державна політика у сфері формування

\footnotetext{
${ }^{1}$ Свропейська конвенція про основні принципи транскордонного співробітництва між територіальними общинами або органами влади, 1993 (Рада Європи). ІАС Консультант <http://consultant.parus.ua/?doc=00P984DEF9> (2021, березень, 22).

2 Окуньовська, Ю. В. (2017) Вплив неурядових організацій Польщі на формування громадянського суспільства в Україні. Політичне життя <http://app.nuoua.od.ua/archive/60_2017/15.pdf> (2021, березень,22).

${ }^{3}$ Колодій, А.(2010). Проблеми і перспективи розвитку громадянського суспільства в сучасній Україні. Думки з приводу. Авторський сайт Антоніни Колодій <http://political-studies.com/wp-content/uploads/ 2010/01/Civil-Society.pdf > (2021, березень, 22).
} 
інститутів та організацій громадянського суспільства регламентувала посилення їхньої взаємодії з органами публічної влади, запровадження громадського контролю за діяльністю влади, проведення регулярних консультацій із громадськістю ${ }^{1}$.

31 січня 2013 р. набрав чинності новий Закон «Про громадські об'єднання». Прийнятий 22 березня 2012 р., він став результатом тривалого законотворчого процесу, активним учасником якого увесь період були представники громадянського суспільства. Новий закон вирішив питання, пов’язані із лібералізацією процедури реєстрації ГО та усуненням адміністративних бар'єрів в їхній діяльності.

Результатом прийняття закону стало збільшення кількості громадських організацій. За даними державної служби статистики України, загальне число зареєстрованих громадських організацій становило за 2015p. - 67911 з яких 22185 належать керівним органам, 45726- відокремленим підрозділам ${ }^{2}$.

Невід'ємним складовим елементом становлення громадянського суспільства в Україні $є$ вплив національних меншин. Значну роль в українському «третьому секторі», зокрема, польської. Вони виконують вкрай актуальну для поліетнічного українського суспільства функцію - представлення групових інтересів польської громади, оскільки «існування легітимізованих інститутів волевиявлення зменшує вірогідність виникнення етнічних конфліктів» ${ }^{3}$.

Дані перепису населення у Польщі 2002 р. показують, що українцями на території Польщі вважають себе близько 27 тис. громадян. Перепис 2001 р. в Україні називає 144 тис. поляків. Тобто 0,3 \% громадян України складають поляки. Найбільше їх проживає у таких областях: Житомирській (49 тис.), Хмельницький (23 тис.), Львівській (19 тис).

В європейському суспільстві «третій сектор» відіграє ключову роль у процесах управління територією, моніторингу діяльності органів влади та реалізації проектів розвитку території тощо. Середнє значення кількості громадських організацій на 1000 осіб прикордонних територій як України, так і Польщі незначно відрізняються. Східні прикордонні області Польщі та західні прикордонні області України активно беруть участь у всіх доступних операційних програмах $Є \mathrm{C} \mathrm{i}$ громадські організації є основними бенефіціарами фінансових ресурсів зі структурних фондів ЄС.

Важливою складовою українсько-польської договірно-правової бази $є$ двосторонні домовленості між суб'єктами адміністративно-територіального устрою України та Республіки Польща, яких загалом налічується понад $470^{4}$.

Становлення правової системи українсько-польської економічної співпраці розпочалося на базі Договору між Україною і Польщею про добросусідство, дружні відносини і співробітництво від 18 травня 1992 р. У документі, зокрема, зазначалося, що обидві держави сприятимуть встановленню й розвитку безпосередніх зв'язків та співпраці між регіонами, адміністративнотериторіальними одиницями та містами України i Республіки Польща. Особлива увага приділятиметься прикордонному співробітництву. Наступним кроком у процесі формування нормативно-правової основи українсько-польської транскордонної співпраці стало підписання 24 травня 1993 р. Урядом України й Урядом Республіки Польща Угоди про міжрегіональне співробітництво, в якій обидві сторони висловили готовність підтримувати таку співпрацю і всіляко сприяти економічному та суспільному прогресу своїх регіонів, особливо прикордонних.

На основі цих документів розпочалася реальна співпраця в економічній і громадських сферах між окремими українськими та польськими містами, районами й повітами. У грудні 1994 р. міська рада м. Перемишля схвалила договір про співпрацю зі Львовом, а в червні 1995 р. було підписано цей договір. У 1997 р. укладено угоду про співробітництво між Перемишлем і Кам'янцем-Подільськом у сферах культури, освіти, спорту, самоврядування й економічної діяльності ${ }^{5}$. Співпрацюють також між собою міста: Люблін, Львів та Краків. За інформацією обласних держадміністрацій, співпраця міст реалізується ефективніше в конкретних проектах через створення спільних підприємств, взаємного відкриття торгових домів, культурних та інших заходів тощо, що можна пояснити більшим досвідом співпраці міст-побратимів.

\footnotetext{
${ }^{1}$ Солошенко, В. (2015). Діяльність європейських неурядових організацій в Україні. Віче, 2, 11-14.

2 Державна служба статистики України (2016). Діяльність громадських об'єднань в Україні у 2015 роиі. Київ, 5.

${ }^{3}$ Когутяк, Ю. (1997). Конфлікт етнічний. PUBLICA <http://www.socd.univ.kiev.ua/PUBLICA> (2021, лютий,27).

${ }^{4}$ Офіційний сайт Посольства України в Республіці Польща (2020). Договірно-правова база між Украӥною та Польщею $<\mathrm{http}: / /$ poland.mfa.gov.ua/ua/ukraine-pl/legal-acts > (2020, грудень, 21).

${ }_{5}^{5}$ Кресло, А. (2005). Польсько-украӥнські стосунки й образ Украӥни у польській пресі (1994-2003). Львів, 91.
} 
Україна має найрозвинутішу мережу співпраці саме з Республікою Польща. Практично всі області України та воєводства Польщі уклали угоди про міжрегіональне та транскордонне співробітництво. Усі 16 воєводств Польщі мають партнера в Україні на рівні області. Найбільше українських партнерів мають Підкарпатське, Люблінське, Лодзьке, Сілезьке та Мазовецьке воєводства. 3 українського боку найбільше польських партнерів мають Львівська, Одеська, ІваноФранківська, Вінницька та Волинська області.

Східні прикордонні області Польщі та західні прикордонні області України активно беруть участь увсіх доступних операційних програмах $€ C$ i громадські організації $\epsilon$ основними бенефіціарами фінансових ресурсів зі структурних фондів $\mathrm{CC}$.

Важливим кроком у напрямку формування нормативно-правової бази українсько-польської співпраці стало прийняття 24 червня 2004 р. Закону України «Про транскордонне співробітництво» ${ }^{1}$ Цим Законом було врегульовано правові, організаційні та економічні питання розвитку транскордонного співробітництва, його фінансову та державну підтримку, дещо розширено повноваження органів місцевого самоврядування і місцевих органів виконавчої влади в цій сфері. Головними напрямками транскордонного співробітництва визначено модернізацію і розвиток транскордонної мережі для збільшення її пропускної спроможності. Передбачено будівництво нових пунктів пропуску через державний кордон України. У планах уряду України - розбудова виробничої та соціальної інфраструктури, розвиток інфраструктури бізнесу та туризму,

Для подальшого розвитку стратегічного партнерства між Україною та Республікою Польща важливе значення має розширення та вдосконалення існуючої договірно-правової бази. На сьогодні ведеться активна робота щодо підготовки двосторонніх документів у сфері торговельно-економічного та енергетичного співробітництва, прикордонної співпраці, транспорту, екології, культурногуманітарного співробітництва, молодіжної політики та військово-технічної співпраці тощо.

Польські організації допомагають використати та перейняти досвід формування громадянського суспільства та дедалі глибше інтегруватися в українське суспільство. Етнічні поляки в Україні долучаються до громадсько-політичного життя держави, виступають дієвим чинником українсько-польського партнерства, яке в умовах глобалізаційних процесів виходить за межі двостороннього співробітництва.

Польські громадські організації, які функціонують в Україні $є$ частиною українського громадянського суспільства та складовою українського «третього сектору». Мережа даних організацій сприяє популяризації польських та європейських цінностей, показує історичний взаємозв'язок появи та розвитку організацій, займається налагодженням стосунків українців 3 Польщею, та встановлює різноманітні етносоціальні контакти.

3 огляду на аналіз установчих документів польських громадських організацій важливе значення має захист прав польських меншин та прав громадян Республіки Польща незалежно від країни їх проживання. Слід підтримувати сучасні способи внутрішньої комунікації полонії та поляків за кордоном. Ключовим є налагодження взаємодії між усіма групами у країнах проживання, тобто полонійними організаціями, молоддю та видатними постатями, лідерами громадської думки.

Для України $є$ важливим та актуальним досвід організацій, які діють у Польщі, зокрема, «Гельсінської з прав людини», «Фундації освіти для демократії», «Фундації розвитку громадянського суспільства», «Фундації суспільно-політичних ініціатив» та ін., які у своїй міжнародній діяльності надають великого значення розвитку демократії та ринкової економіки у контексті транскордонного співробітництва.

Особливості діяльності польських громадських організацій у контексті розбудови українського громадянського суспільства проявляється у: налагодження міжнаціональних відносин між українцями та поляками, популяризація культури та європейських цінностей, вивчення спільної історії та відновлення історичної справедливості.

3 огляду на аналіз установчих документів польських громадських організацій важливе значення має захист прав польських меншин та прав громадян Республіки Польща незалежно від країни їх проживання. Слід підтримувати сучасні способи внутрішньої комунікації полонії та поляків за кордоном. Ключовим є налагодження взаємодії між усіма групами в країнах проживання, тобто полонійними організаціями, молоддю та видатними постатями, лідерами громадської думки.

\footnotetext{
1 Закон про транскордонне співробітництво, 2004 (Верховна Рада України). Відомості Верховної Ради України , 45, 499.
} 
В Україні активно працюють такі польські організації: Спілка поляків України, Федерація польських організацій в Україні, Об’єднання поляків «Полонія» (яке функціонує у Житомирі, Запоріжжі, Кропивницькому, Могилеві-Подільському), Національно-культурне товариство «Згода», Польський інститут у Києві, Спілка поляків Донбасу, Союз поляків «Білий орел» ${ }^{1}$.

Важливими осередками інтенсифікації та розвитку українсько-польського транскордонного співробітництва виступають єврорегіони «Карпатський» та «Буг», які діють в українсько-польському прикордонні. Єврорегіон «Карпатський» функціонує на основі Декларації про співпрацю спільнот, які мешкають на території Карпатського регіону, а також на основі статуту Міжрегіональної Асоціації «Карпатський єврорегіон», що були підписані 14 лютого 1993 р. в м. Дебрецені (Угорщина) міністрами закордонних справ України, Польщі та Угорщини. Діяльність єврорегіону «Буг» регулюється Угодою про створення Транскордонного Об’ єднання «Сврорегіон Буг», підписаною 29 вересня 1995 р. в м.Луцьк між Волинською областю та колишніми Холмським, Люблінським, Тарнобжезьким і Замостським воєводствами Республіки Польща (до зміни адміністративного поділу цієї країни в 1999 році) ${ }^{2}$.

За ініціативи місцевих громадських організацій у січні 2004 року на Волині реалізується українсько-польсько-білоруський проект «Евротрикутник приязні: Люблін - Луцьк - Брест», підтриманий міжнародною програмою PHARE. Основна мета проекту полягала у опрацюванні спільної концепції розвитку туризму єврорегіону «Буг». 3 липня 2006 р. по січень 2007 року було реалізовано проект «Туризм без кордонів - промоція туристичних центрів Сврорегіону Буг». Завдяки проекту було зміцнено туристичний сектор міст Любліна, Луцька, Бреста через модернізацію системи обслуговування та промоції транскордонного туризму, інноваційність та оптимізацію попередньо здійснених заходів щодо розвитку туризму на теренах Єврорегіону Буг.

Розглянемо найбільш активні польські громадські організації, які займаються транскордонним співробітництвом з Україною. За інформацією Посольства України в Республіці Польща, розвиток українсько-польського транскордонного співробітництва здійснюється у декількох площинах. На рівні центральних органів виконавчої влади двох країн з українського боку це питання координується Міністерством регіонального розвитку, будівництва та житлово-комунального господарства України, Міністерством закордонних справ, Міністерством інфраструктури та Міністерством економічного розвитку і торгівлі, з польського боку - Міністерством внутрішніх справ, Міністерством регіонального розвитку та Міністерством закордонних справ.

Для вирішення ключових питань українсько-польського міжрегіонального співробітництва на міжурядовому рівні створено інституційний механізм - Українсько-польську Міжурядову Координаційну Раду з питань міжрегіонального співробітництва (далі МКРМС). МКРМС приймає рішення з ключових питань міжрегіонального співробітництва, визначає загальні напрямки і головні принципи його розвитку, надає компетентним органам України та Польщі відповідні пропозиції, розроблює спільні програми діяльності, спрямовані на розвиток міжрегіональної співпраці та в цілому координує міжрегіональне співробітництво на рівні областей України та воєводств Республіки Польща ${ }^{3}$.

Окрім цих інституцій в Україні діє велика кількість громадських організацій. Розглянемо найбільш активні організації.

Спілка поляків України - заснована у 1992 р. є добровільною незалежною всеукраїнською громадською організацією, яка об'єднує громадян України на основі спільних інтересів для реалізації мети та завдань. Згідно статуту організації, головною метою спілку поляків України є національне відродження осіб польського походження, пробудження і розвиток національної самосвідомості, зберігання та розвиток польської культури, основних елементів своєї самобутності, мови, традиції та культурної спадщини. Популяризація спільної історії польського та українського народів, зміцнення дружби між поляками та українцями, іншими народами з метою сприяння толерантності та розвитку культурного плюралізму ${ }^{4}$.

\footnotetext{
${ }^{1}$ Фролов, С. (2015). Поляки в Україні, що ховається за показником 0,3. Ресурсний центр ГУРТ

$<$ http://gurt.org.ua/blog $>$ (2021, березень, 21).

2 Посольство України в Республіці Польща (2021). Міжрегіональне співробітництво між Україною та Польщею $<\mathrm{https://poland.mfa.gov.ua/ua/ukraine-pl/regions}>$ (2021, березень, 18).

${ }^{3}$ Восточно-европейский научный журнал (2017). Перспективи розвитку міжсрегіонального та транскордонного співробітництва західних областей України <https://eesa-journal.com/2017/04/06/perspektivi-rozvitkumizhregionalnogo-ta-transkordonnogo-spivrobitnictva-zaxidnix-oblastej-ukra\%D1\%97ni/> (2021, березень, 18).

${ }^{4}$ Спілка поляків України (2017). Статут громадської організаціï <http://z-p-u.org/wp-content/uploads/2014/05/ Статут-СПУ-2016.pdf> (2021, березень, 18).
} 
Союз поляків «Білий орел» має на меті діяльності спрямовану на: всебічний розвиток та популяризацію польської культури та народних традицій у місті Львові, єднання та підтримку етнічних поляків, взаємодопомогу, виховання підростаючого покоління в дусі національних традицій, ідеалів гуманізму, милосердя, соціальний захист своїх членів, допомогу ветеранам.

Основним завданнями організації $є$ : всебічний розвиток та популяризація польської мови та культури; підтримка та розвиток Польських традицій, звичаїв, мови, мистецтва; проведення та координація діяльності спрямованої на налагодження ділових зв'язків та контактів між етнічним поляками, що проживають у Львові та Польщі; сприяння членам організації в отриманні відповідної освіти в польських вищих навчальних закладах; організація соціальної допомоги полякам; сприяння і надання матеріальної допомоги, правового захисту ініціативам і починанням громадськості які скеровані на примноження і розвиток польських національних традицій; підтримка поляків що проживають у Львові ${ }^{1}$.

Вагомий внесок у розбудову громадянського суспільства в Україні робить Польсько-українська фундація співпраці (ПАУСІ), заснована в квітні 2005 року. Вона докладає зусиль, щоб передати успішний досвід Варшави під час переходу до ринкової економіки, допомогти Україні інтегруватися до європейських та євроатлантичних структур шляхом запровадження європейського, зокрема, польського досвіду. Місією фундації також $є$ інтенсивний транскордонний обмін знаннями та досвідом у ключових сферах, що впливають на розвиток людського капіталу й формування громадянського суспільства ${ }^{2}$.

Польська фундація імені Стефана Баторія $є$ незалежною, некомерційною неурядовою організації зі статусом суспільно-корисних організацій, яка працює на користь зближення між Європейським Союзом і його східними сусідами, зокрема, України і Білорусії. Організація підтримує заходи зі сприяння обміну між країнами Центральної та Східної Свропи досвідом, пов'язаним 3 політичними змінами, побудовою громадянського суспільства та вирішенням соціальних проблем. Завдяки чому прагне підвищити роль польських неурядових організацій на міжнародній арені в тому числі і в Україні ${ }^{3}$.

Окремо слід виділити міжнародну громадську організацією, яка об'єднує на засадах добровільності громадян України та інших держав, це «Україна-Польща-Німеччина» (UPD). Презентація UPD відбулася в липні 2007 року в німецькому місті Нойштреліці. Ця МГО активно сприяє зміцненню дружби та розвитку тісного співробітництва народів України, Польщі й Німеччини, задоволенню та захисту законних соціальних, економічних, творчих, вікових, національнокультурних, спортивних та інших інтересів членів організації.

Показово, що за сприяння цієї організації та об'єднання «Україна-Польща» налагоджено співпрацю між більш як 120 територіальними громадами Вінницької області й адміністративними одиницями 10 воєводств Республіки Польща. У ролі структурного підрозділу виступає підприємство «Господарчий дім», метою якого $є$ встановлення прямих зв'язків із фірмами та організаціями зарубіжжя щодо розвитку промислового виробництва, будівництва, сільського господарства й торгівлі.

Для України $є$ важливим та актуальним досвід організацій, які діють у Польщі, зокрема, Гельсінської з прав людини, Фундації освіти для демократії, Фундації розвитку громадянського суспільства, Фундації суспільно-політичних ініціатив та ін., які у своїй міжнародній діяльності надають великого значення розвитку демократії та ринкової економіки на пострадянському просторі, включаючи й Україну. Головним завданням даних організацій є розробка спеціальних програм для стажування українців у польських структурах місцевого самоврядування та в неурядових організаціях. Активну роботу проводить Інститут на користь демократії в державах ЦентральноСхідної Європи, зокрема, реалізуються його програми: «Центр плюралізму», «Підтримка місцевої демократії в Україні», «Підтримка вільних засобів масової інформації в Україні», «Підтримка модернізації сільського господарства в Україні» та ін. Значна частина цих програм спонсорується західними приватними фондами, а в їх реалізації беруть участь українські поляки.

\footnotetext{
${ }^{1}$ Союзу поляків Білий орел (2019). Статут громадської організації <http://orzelbialy.org.ua> (2021, березень, 18).

2 PAUCI (2014). Фундаиія ПАУСІ відкрила «Бізнес-інкубатор» спільно з Харківським начіональним університетом міського господарства імені О. М. Бекетова $<$ https://pauci.org/ua/news/2> (2021, березень, 18).

${ }^{3}$ Статут фундації імені Стефана Баторія (2018) <http://www.batory.org.pl/o_fundcji> (2021, березень, 18).

${ }^{4}$ Міжнародне товариство «Україна- Польща-Німеччина» (2021). Про товариство

$<$ http://ukrpolgerm.com/content/about> (2021, березень, 18).
} 
Важливим етапом транскордонного співробітництва став 2008 рік, коли Польщею за підтримки Швеції була представлена ініціатива Східне партнерства. Це політика Європейського Союзу (СС), що має на меті зміцнення відносин зі східними сусідами $Є С$ і $є$ продовженням східного напрямку існуючої Європейської політики сусідства. Ця ініціатива передбачала участь 6 країн Східної Європи України, Молдови, Білорусі, Грузії, Вірменії та Азербайджану.

20 березня 2009 року Рада ЄС остаточно затвердила проект Східного партнерства, оголосивши про те, що його офіційний старт відбудеться 7 травня 2009 року у Празі. 3 точки зору транскордонного співробітництва проект Східного партнерства трансформувався в ЕаРТС - програми територіального співробітництва країн Східного партнерства. Основна мета була досягнута через сприяння сталому транскордонному співробітництву країн Східного партнерства 3 метою створення сприятливих умов для пошуку спільних рішень загальних проблем прикордонних територій.

Висновки. Україна має значні потенційні можливості щодо розвитку транскордонне співробітництва, оскільки 19 з 25 ії регіонів є прикордонними, а зовнішній кордон - найдовший серед європейських країн. Особливістю транскордонне співробітництво України є те, що воно відбувається не тільки на кордонах України $з$ країнами Європейського Союзу, а і на кордонах 3 країнами, що не входять до складу $\mathrm{CC}$, - Російською Федерацією, Білоруссю та Молдовою. Так, протяжність кордонів із Російською Федерацією становить близько 2300 км, з країнами $Є С-1390$ км, Білоруссю та Молдовою - понад 2300 км. В Україні транскордонне співробітництво сьогодні розглядається у двох площинах - як інструмент розвитку прикордонних територій і як чинник реалізації ії євроінтеграційних прагнень.

У розвитку транскордонного співробітництва на сучасному етапі розвитку дипломатичних відносин актуальність полягаю в українсько-польських відносинах. Польща, як і Україна, має відносно не довгий досвід функціонування громадянського суспільства, проте демократичні та інституційні зміни які уже відбулися у польському суспільстві $є$ актуальними для вивчення даної теми. Перспектива подальшої співпраці полягає у можливості залучення в рамках реалізації окремих проектів фінансових коштів ЄС. На даний час діє Програму транскордонного співробітництва «Польща-Білорусь-Україна» ЄІСП на 2014-2020 рр., яка $\epsilon$ ефективним інструментом для використання коштів СС органами місцевої влади та самоврядування, а також неурядовими організаціями обох держав для реалізації проектів у сфері транскордонного співробітництва. Методи та форми взаємодії влади 3 «третім сектором» базуються на таких основних принципах, як співробітництво, довіра та наявність діалогу.

\section{References:}

1. Derzhavna sluzhba statystyky Ukrayiny (2016) [State Statistics Service of Ukraine (2016)]. Diyalnist hromadskykh obyednan v Ukrayini u 2015 rotsi [Activities of public associations in Ukraine in 2015]. Kyiv, 5. [in Ukrainian].

2. Dohovirno-pravova baza mizh Ukrainoiu ta Polshcheiu. [Legal framework between Ukraine and Poland.] Ofitsiinyi sait Posolstva Ukrainy v Respublitsi Polshcha.[ Official site of the Embassy of Ukraine in the Republic of Poland] <http://poland.mfa.gov.ua/ua/ukraine-pl/legal-acts > [in Ukrainian]. (2020, December, 21).

3. Yevropeiska konventsiia pro osnovni pryntsypy transkordonnoho spivrobitnytstva mizh terytorialnymy obshchynamy abo orhanamy vlady (The European Convention on the Basic Principles of Transcordon Spivrobitnity Migrant Territorial Communities Abo Orhans Vlady)(1993) $<$ http://consultant.parus.ua/?doc=00P984DEF9 > [in Ukrainian]. (2021, March, 22).

4. Kohutiak Yu.(1997) Konflikt etnichnyi [Ethnic conflict] < http://www.socd.univ.kiev.ua/PUBLICA $>$ [in Ukrainian]. (2021, February, 27).

5. Kolodii A.(2010) Problemy i perspektyvy rozvytku hromadianskoho suspilstva v suchasnii Ukraini [Problems and Prospects for Development of Khromadyanskoho Suspension in Ukraine] < http://political-studies.com/ wp-content/uploads/2010/01/Civil-Society.pdf > [in Ukrainian]. (2021, March, 22).

6. Kreslo A. (2005) Polsko-ukrainski stosunky y obraz Ukrainy u polskii presi (1994-2003). [The Polish-Ukrainian relationship y the image of Ukraine and Polish pressure (1994-2003)]. Lviv, 2005. S. 91.[in Ukrainian].

7. Mizhnarodne tovarystvo «Ukraina - Polshcha - Nimechchyna» [International partnership "Ukraine - Poland Nimechchyna]. <http:// ukrpolgerm.com/content/about> [in Ukrainian]. (2021, March, 22).

8. Mizhrehionalne spivrobitnytstvo mizh Ukrainoiu ta Polshcheiu. [Interrenional spirits of Ukraine and Poland]. $<$ https://poland.mfa.gov.ua/ua/ukraine-pl/regions> [in Ukrainian]. (2021, March, 18).

9. Okunovska Yu. V. (2017) Vplyv neuriadovykh orhanizatsii Polshchi na formuvannia hromadianskoho suspilstva v Ukraini.[ The inflow of uncommon organization of Poland into the formation of Khromadyanskoho suspension in Ukraine.] Politychne zhyttia. [Political life] no 60. 125-134 [in Ukrainian].

10. Perspektyvy rozvytku mizhrehionalnoho ta transkordonnoho spivrobitnytstva zakhidnykh oblastei Ukrainy. [Prospects for the development of inter-renional and transcordon spivrobitnity of the zahid regions of Ukraine.] 
(2019) < https://eesa-journal.com/2017/04/06/perspektivi-rozvitkumizhregionalnogo-ta-transkordonnogospivrobitnictva-zaxidnix-oblastej-ukra\%D1\%97ni/> [in Ukrainian]. (2021, March, 18).

11. Pro transkordonne spivrobitnytstvo. (Verkhovna Rada Ukrainy).[ About the transcordon spirits. (Verkhovna Rada of Ukraine)].Vidomosti Verkhovnoi Rady Ukrainy [News of the Verkhovna Rada of Ukraine]. 2004, № 45, st.499) [in Ukrainian].

12. Soloshenko V.(2015) Diialnist yevropeiskykh neuriadovykh orhanizatsii v Ukraini.[Diyalnist of European uncommon organizations in Ukraine] <www.viche.info $>$ [in Ukrainian]. (2021, February, 27).

13. Statut hromadskoi orhanizatsii «Spilka poliakiv Ukrainy» (2017). [ Statute of the Chromadic organization "Splilka Poles of Ukraine"] < http://z-p-u.org/wp-content/uploads > [in Ukrainian]. (2021, March, 18).

14. Statut hromadskoi orhanizatsii soiuzu poliakiv «Bilyi orel» (2019). [Statute of the Chromadic organization to the White Eagle Union of Poles (2019)] < http://orzelbialy.org.ua > [in Poland]. (2021, March, 18).

15. Statut fundatsii imeni Stefana Batoriia. (2018). [Statute of the Stefan Batory Foundation. (2018)] $<\mathrm{http}$ ://www.batory.org.pl/o_fundcji > Statut hromadskoi orhanizatsii soiuzu poliakiv «Bilyi orel» (2019) $<$ http://orzelbialy.org.ua $>$ [in Poland]. (2021, March, 18).

16. Frolov Ye.(2015) Poliaky v Ukraini, shcho khovaietsia za pokaznykom 0,3. [Poles in Ukraine, which is behind the indicator 0.3]. Resursnyi tsentr HURT - 2015. [Resource Center HURT-2015.] <http://gurt.org.ua/blog> [in Poland]. (2021, March, 21).

17. Fundatsiia PAUSI vidkryla «Biznes-inkubator» spilno z Kharkivskym natsionalnym universytetom miskoho hospodarstva imeni O. M. Beketova. - 6 chervnia 2014 r.[ Fundatsiia PAUSI vidkryla "Biznes-inkubator" spilno z Kharkivskym natsionalnym universytetom miskoho hospodarstva imeni O. M. Beketova. - 6 chervnia 2014 r] $<$ http://www.pauci.org/ua/ news $>$ [in Ukrainian]. (2021, March, 18). 